\title{
Discourses of Non-Formal Pedagogy in Two Youth-Oriented Indonesian Environmental NGOs
}

\author{
Pam Nilan ${ }^{1}$ \\ ${ }^{1}$ School of Humanities and Social Science, University of Newcastle and School of Asian Studies, University of \\ Western Australia, Australia \\ Correspondence: Pam Nilan, School of Humanities and Social Science, University of Newcastle, 2308. New \\ South Wales, Australia. Tel: 61-2-4921-5912. E-mail: Pamela.Nilan@newcastle.edu.au
}

Received: April 14, $2015 \quad$ Accepted: June 12, $2015 \quad$ Online Published: July 6, 2015
$\begin{array}{ll}\text { doi:10.5539/ass.v11n21p162 URL: http://dx.doi.org/10.5539/ass.v11n21p162 }\end{array}$

\begin{abstract}
This article compares two youth-oriented ENGOs (Environmental Non-Government Organisations) in Indonesia. Comparative analysis focuses on how the two organisations provide discourses that configure differently the pedagogic space of experiential learning for children and young people. Despite an apparent low level of environmental awareness generally among the Indonesian population there does seem to be some enthusiasm for environmental activities among certain groups of young people. However, it seems different kinds of young people are drawn to different kinds of environmental activities. Conceptually, if we accept that there is an imagined space of the nation (Anderson, 1991) we can logically propose an imagined national space of the physical environment. Thus different agents of change will imagine and configure this space differently so that certain kinds of engagement and learning follow. Escobar (1999) points out that what we perceive in the environment as "natural" is always also cultural and social. So for example, transnational logging companies understand the Indonesian forests as a natural resource to be exploited, while student nature-lover groups Mahasiswa Pencinta Alam - constitute forests as recreational places to camp and walk in nature. This paper examines two ENGOs designed to appeal to young Indonesians: Sahabat Alam - Friends of Nature - founded in 2008 by a 12 year old schoolgirl after Jakarta flooding, and Tanam Untuk Kehidupan - Planting for Life - an arts collective which aims for learning about the environment through creative practices and festivals in Salatiga.
\end{abstract}

Keywords: non-formal education, environmentalism, Indonesia, NGOs, young people

\section{Introduction}

\subsection{Indonesia and Environmental Awareness}

The Indonesian archipelago is a site of extraordinary tropical biodiversity. However, a long history of natural resource extraction has stripped forests away and damaged ecosystems, sometimes irreparably. The islands are vulnerable to rising sea levels and geothermal activity. Illegal forest burning blankets the nearby region in thick, choking smoke every year. Concerted action needs to be taken now to reverse damaging environmental trends that threaten not only the nation, but the region and the world, since Indonesia is the world's third largest emitter of greenhouse gases that cause global climate change (Measey, 2010, p. 31). Yet relatively little is happening on the ground.

Indonesia is the largest Muslim majority country in the world, with a population of over 250 million. The median age is 28.9 years, and 44 per cent of the population lives in urban areas (BPS, 2012). Indonesia is currently ranked at only 121 of 187 countries according to the 2013 Human Development Index. There are still high levels of poverty, unemployment and corruption (World Bank, 2013). The current strong economic growth rate signals the expansion of the urban middle class, incurring higher rates of "domestic consumerism, energy usage and CO2 emissions" (Savage, 2012, p. 244), with more industry, more vehicles, larger houses, more roads and greater stress on already weak urban infrastucture such as water supply, drainage, rubbish disposal and sewerage. Urban prosperity has also seen an increase in resource-intensive shopping mall culture (Douglass et al., 2008). In other words, as the nation has grown economically, so has the negative impact on the urban environment.

The countryside has also felt the impact. 80 per cent of Indonesian greenhouse gas emissions result from changed land use following logging and forest/swamp fires, especially deforestation (World Bank, 2011). The 
Kyoto Protocol was signed by Indonesia in 1998 and ratified in 2004. However, despite policies and regulations to reduce greenhouse emissions by roughly 26 per cent (World Bank, 2010), and the goal of a 41 per cent reduction with donor assistance, progress has been slow. Legal implementation and enforcement remains very weak (Measey, 2010, p. 43). Most deforestation occurs in just 10 provinces, but Riau, Central Kalimantan and South Sumatra account for over half of all forest degradation and loss (World Bank, 2009). The managed agricultural lands of traditional Indonesia were characterised by fallow-cropping cycles that preserve the land and stabilise carbon in the soil. However, global demand for food and biofuels has driven high capital agricultural development. Indonesia has experienced one of the most rapid plantation expansions worldwide (Carlson et al., 2012). Extensive company-owned farms now occupy many parts of Indonesia that were once forested, while agribusiness in other parts of the country has eclipsed traditional forms of agriculture. There is reliance on artificial fertilisers, pesticides and herbicides for continuous high-yield crop production (Setiawan, Stoetter, Sartohadi, \& Christanto, 2009). Moreover, monoculture plantations in Indonesia deploy very intensive soil tillage without proper soil conservation, resulting in soil erosion and depleted soil fertility (Setiawan et al., 2009).

In settled areas, even the casual observer will find public spaces littered and polluted. Waterways are contaminated with refuse, sewerage and toxic sludge. Air pollution daily reaches dangerous levels in the major cities. There is little regulation of, or accountability for, activities that pollute the local environment, and minimal public consciousness of the consequences of littering and illegal waste disposal, or of non-approved building and industrial development. Ignorance, lack of regulation and accountability, and minimal sense of responsibility appears to extend from the bottom to the top. Pro-environment sentiments are expressed in political circles and in the press, but little happens in practice. Nevertheless, environmental groups do exist and are taking action to raise the consciousness of the population.

Yet it is only 15 years since the country emerged from authoritarian rule to embrace democracy. Environmentalism in Indonesia is therefore unlikely to resemble environmentalism in other places, especially western countries. Non-western countries bear better comparison. For example, Iran shows some similarities to Indonesia because the country experienced an authoritarian regime where environmental destruction was permitted, followed by a period in which "pro-environmental groups" emerged (Fadaee, 2011, p. 82). Similarly, in China an "active green community" emerged after the mid 1990s (Stalley \& Yang, 2006). Activists were mostly under 40 years old, and more than half had university education (Xie, 2010). This matches the "environmental sympathiser" profile in both urban Iran (Fadaee, 2011, p. 82) and urban Indonesia (Sudamardi et al., 2001; Hadiniwata, 2003). In short, middle class young Indonesians are those most likely to get involved in youth-oriented environmental NGOs.

\subsection{Environmentalist Views}

Broadly speaking, environmentalist views in Indonesia are most often framed around conservation concerns (di Gregorio, 2012). There is much rhetoric about protecting the symbolic community of the archipelago; construed as a natural wonderland and matter of national pride on the global stage. Online and social media environmentalist discourse in Indonesia emphasises preservation of the unique flora and fauna of the archipelago, its world famous natural beauty, as yet undiscovered miracle cures from the rainforest, the potential for lucrative eco-tourism, and so on. This set of discourses approximates "the romantic gaze" of environmentalism (Macnaghten \& Urry, 1998). Taking Escobar's (1999) point that what we perceive in the environment as "natural" is always cultural and social, the romantic gaze of Indonesian conservationism expresses a middle-class, nationalist perception of nature. It is distinguishable from the pragmatic perceptions of nature among local peasant farmers in the countryside, for example, which are based on the direct experience of subsistence agriculture.

Coverage of environmental problems observed by the author in the Indonesian press in 2013/2014 included: deforestation, forest-burning haze, loss of agricultural land, expansion of monoculture plantations, mining impacts, species decline, degradation of waterways and ocean, soil erosion and depletion, air and water pollution, weather changes, lack of sewage and sanitation, reliance on fossil fuels, waste disposal, greenhouse gas emissions. Yet headlines about major disasters (floods, mud slides, fires, volcanoes) have probably stimulated greater concern among the population than some of the other environmental problems listed above. Relevant to this point, Savage (2012, p. 234) suggests that in Southeast Asian countries like Indonesia, prolonged exposure over centuries to large-scale environmental hazards may mean that people and communities still have "a resigned, fatalistic outlook" at the present time, even though environmental threats are much worse, and result much more demonstrably from human actions. 
There seem to be few government-sponsored incentives or sanctions to encourage responsibility for risky behaviour, such as littering, pollution and illegal land-clearing. Environmental activist groups seek to bring issues to political debate and public attention but with little success. The Indonesian Minister for the Environment wrote in 2004, "we must acknowledge that our attention to and consciousness of environmental problems is still very low. This is caused by the fact that most people in Indonesian society have not yet awoken to a real perception of the environment" (Kementerian Lingkungan Hidup, 2004, p. ix, translated by Lyn Parker). A significant international report on Indonesia concurs, stating that "environmental values are not deeply embedded in society". It is argued the consequence is "undervaluation of natural resources and environmental services" (World Bank, 2011). However, Bohensky, Smajgl, and Brewer (2012) did find awareness of global warming among Indonesian families, which strikes a note of optimism. The authors surveyed 6,310 households in East Kalimantan in 2007 and in Central Java in 2008. 81.9 per cent of respondents had observed climate change and 70.7 per cent perceived it as a risk. 38.9 per cent were adapting to its impacts and 28.2 per cent were taking proactive measures. Their most significant finding however, was that 31.8 per cent of people had observed climate change and perceived it as a risk but were taking no action (Bohensky, Smajgl, \& Brewer, 2012, p. 349). It seems possible then that the environmental awareness of well-informed Indonesians does not often extend beyond information and perception to environmentally significant behaviour, either individual or collective.

Disseminating more information per se is not necessarily the answer. "Knowledge is a necessary, however not sufficient precondition for developing pro-environmental moral norms and attitudes" (Bamberg \& Moser, 2007, p. 22, my emphasis). In other words, deep environmental learning needs to take place if entrenched social and cultural behaviours are to change. A study of student environmental awareness in the Philippines concluded that,

Paradigms are deeply ingrained in societies and are imbibed by successive generations born into them and changes in paradigms cannot be realized through intellectual discussion alone ... [but by] experiences that touch students deeply (Galang, 2010, p. 182).

As Giddens (2011, p. 3) points out, "people find it hard to give the same level of reality to the [environmental] future as they do to the present (...) one shouldn't underestimate the sheer force of habit". It would seem that a change in intersubjective reality is needed for young people to take themselves up as active environmentalists. It is here that hands-on experiential learning by young people in ENGOs might be significant for the future of the environment through overcoming, in a peer group context the residual "resigned, fatalistic outlooks" identified by Savage (2012, p. 234).

\section{Environmental Learning: Formal and Non-Formal}

\subsection{School Learning}

Factual information about the environment learned at school may have little effect on children's pro-environmental behaviour (Wray-Lake, Flanagan, \& Osgood, 2010). Kollmuss and Agyeman (2002) argue that the belief that it does follows the naïve assumption of a linear progression from gaining information about the environment to developing pro-environmental awareness and subsequent pro-environmental behaviour. This cannot be assumed. As Galang (2010, p. 177) points out, it is not "axiomatic that once awareness sets in, people do the right thing by the environment". Something deeper than individual awareness of facts has to develop before group behaviour will change.

Indonesia has introduced environmental components to both the primary and secondary school curriculum. However, although these units of learning are supposed to cover not just environmental knowledge, but how human behaviour affects sustainability (Parus, 2005), in practice they do not. Most teaching in school about the environment remains confined to traditional science subjects (Kollmuss \& Agyeman, 2002). Moreover, there is emphasis in the primary school syllabus on Indonesia's rich natural resources and their potential exploitation (Parker, 2011). Furthermore, traditional teacher-focused pedagogy in Indonesian schools has long used rote learning tested by examination using multiple choice questions and short answers, which does not encourage critcical enquiry or reflection. Despite reforms, much teaching still follows this model (Parker \& Nilan, 2013, p. 85). So with little exposure to anything but rote learning of environmental facts in school, Indonesian pupils' community-engrained habits and habitual ways of regarding the natural world seem unlikely to change. One cannot ignore the impact of the media, of "how television teaches us to be green" (Inthorn \& Reder, 2011, p. 37), for example. But here, once again, it cannot be assumed that nature programs, nationalist boasting, sensational headlines or gloomy predictions will be followed by any kind of behavioural change. 


\subsection{Extra-Curricular Learning}

In Indonesia, extra-curricular engagement of young people with the natural environment often happens through Scouts or nature clubs. Mahasiswa Pencinta Alam (Student Nature Lovers) are possibly "the most well-known form of environmentalism in Indonesia" (Crosby, 2013). The clubs are present on most university campuses and in many secondary schools, offering bushwalking, mountaineering, rafting and climbing trips, for example. However, it has been argued that such activities centre on conquering wilderness rather than appreciating and comprehending it. Cochrane reports that in a popular Indonesian national park at peak times, "crowds of young people dressed in militaristic clothing" hike noisily along the trails. They are "evidently seeking neither solitude nor tranquility". The researcher concludes that enjoyment by Indonesians of natural beauty spots is rooted in an anthropocentric relationship with nature rather than a biocentric one (Cochrane, 2006, pp. 989-991). Given the colonial history of the nation this should not be surprising (see Tsao, 2013).

In a western context, Riemer, Lynes, and Hickman (2014) studied the role of non-formal education in how young people become activists. They point out that although formal environmental education may directly engage environmental awareness and practice among young people, non-formal learning programs are also important,

While some of these youth were engaged by educators in formal settings, there are also many who became engaged because they participated in youth-focused environmental programmes outside the formal sector. Many such programmes exist and seem to make a difference (Riemer et al., 2014, p. 554).

If direct experience of the environment carries most capacity to change thinking and precipitate action (Kusmawan, 2007), then youth-oriented environmental ENGOs are important. Nomura (2009, p. 622) maintains that "NGOs are very active providers of environmental education in Indonesia". Through non-formal education they encourage young people to learn about the environment by doing things in groups to save and preserve the natural world. Accordingly, this article compares two non-formal environmental learning contexts for children and young people. The two ENGOs featured here both attempt the "conscientization" (Freire, 1997, p. 27) of the young people who learn by doing in their offered activities. Conscientization in this context means attaining a deep awareness of the value of the natural world and their own capacity to protect and nurture it. Through examining what the two ENGOs offer young people, we can see how they differ in their implicit pedagogical drive to produce particular kinds of environmentally active citizens in the next generation.

\section{Method}

As stated above, the concern here is with what the two ENGO websites and linked pages can tell us about what kind of non-formal learning experiences are promised young people, and how the two ENGOs differ in their implicit pedagogical drive to produce particular kinds of environmentally active citizens in the next generation of Indonesians. The two ENGOs were selected because they both have considerable web presence. Both are keen to attract international sponsorship, so the websites are attractive, well-developed and list impressive numbers of hits. Careful reading by the author identified quite different representations of pedagogic discourse in what young people were invited to do if they became actively involved in the organisation. A comparative analysis was undertaken to unpack these representations and the ideal future environmental citizen which might be produced.

Treating the the two websites as texts, the analysis proceeded first by content analysis. That is, simple counting of the most frequent words/phrases and images (Babbie, 2010). This allowed the categorisation of common and dissimiliar elements in the two ENGO sites. The second stage was discourse analysis (see Gee, 2014), which made use of the earlier content analysis to derive categories of a deeper, constitutive nature. Here the term discourse refers to a set of ideas, concepts and beliefs that represent a body of influential knowledge in the social world. For example, the discourse of pedagogy includes ideas about learning and teaching. Within the broad discursive field of education, learning and having fun might be seen as antithetical practices for youth in the formal context of schooling, but not in the informal educational context where alternative pedaogical discourses often prevail. Once the comparative analysis was completed, it was summarised in a table, which is included below.

\section{Results}

\subsection{Sahabat Alam}

Sahabat Alam (Friends of Nature) offers non-formal environmental education for children and young people through activities offered on a colourful bilingual website. Sahabat Alam was founded in 2008 by 12 year old schoolgirl Adeline Tiffanie Suwana after extensive flooding in Jakarta. With her friends she re-planted coastal 
mangroves. Subsequent conservation programs earned Sahabat Alam international recognition and financial support. The website (www.sahabat-alam.com) states (in English): "nature and all its elements are precious treasures for the young generations as they are the world's successors in the future". The aim is to "bring young generations back to nature" by taking "environmental actions". In her 2011 speech to the Malaysia-China Chamber of Commerce on receiving the Golden Green Award, young director Adeline said, "with our small hands, we can make a difference".

Apart from the listed program of activities, the bilingual website itself expresses a specific discourse of learning about the environment, and thereby implies an ideal learner as subject. Designed to appeal to children and early teens, it features bright colours and cartoon-like graphics of ribbons, flowers, stems, leaves, butterflies and stars. In photos everyone is smiling and having fun. Visual imagery depicts two key figures with whom children and young teens might identify. The first is young Adeline herself, still only 18 years old at the time of writing. She dominates the photo gallery on the website; demonstrating replanting activities to children and early teens, leading school groups through the forest, meeting members wearing identical teeshirts, and shaking hands with visiting dignitaries. A caption states that Sahabat Alam members are/will be "international environment ambassadors".

The second figure is an anthropomorphic rabbit of indeterminate gender who tells a simple, heroic story in a sliding sequence of six naïvely-syled coloured pencil drawings. It is titled SAVE THE PLANET. In the first slide, an orange-tinted earth is being cooked in a frypan. The rabbit says in a speech bubble, "WOW ... The earth is on fire!!!". In the next slide the rabbit is wearing a space suit and asking "Do we have to move to another planet?". In the third slide the rabbit firmly wags a finger, "NO! With our small hands, WE can SAVE the Earth". In the fourth slide the rabbit is planting a tree and depositing trash in a bin, "STOP littering" and "PLANT some trees". In the fifth slide the rabbit is riding a bicycle - "USE Eco-friendly vehicles"; "SAVE the energy"; and "CONSERVE the water". In the final slide the rabbit is happy. There is a bright green and blue earth in the background: "Let's SAVE our Earth A.S.A.P (As Soon As Possible)".

\subsubsection{Discussion}

Dimitriadis (2009) makes the argument that the multi-media texts of popular culture have a pedagogical effect on the young people who engage with them. Similarly, the text of the Sahabat Alam website provides a pedagogical discourse for young Indonesians interested in the environment. A common optimistic phrase in Indonesia is "agent of change" - always written in English (see for example Samartan, 2009; Ifham \& Helmi, 2002). Both director Adeline and the rabbit match this ideal of agent of change; they are saving the environment through their conscious actions. Therefore, young Indonesians are implicitly invited to understand themselves as potential agents of change through constituting themselves as sahabat alam - friends of nature, manifested through participating in the listed activities. The ideal learner-as-doer then, is already not only constituted as a nascent environmentalist, but is able to read English, and would like to become a cosmopolitan citizen - an international environmental ambassador. So to save the natural environment and become an important agent of change in the world like Adeline, they can pay to join the non-formal educational activities and have fun at the same time.

The promise of learning by doing is everywhere. Advertised activities include: planting trees, coral reef and mangrove re-planting, fish breeding, cleaning marine debris from beaches, protecting Hawksbill Turtle hatchlings and butterfly conservation. The website also offers another form of learning: "the existence of a program that allows children to go back to nature is very important". So expeditions are organised to national parks so that "young generations help protect the natural environment; understand the value of Indonesian flora and fauna's richness; observe and study the undisturbed natural environment; protect species from human activity; enjoy and appreciate the natural environment; promote eco-tourism" (www.sahabat-alam.com). Listed workshops in 2013 included Using Natural Dyes and Plants for Medicine. Seminars included Save the Planet, Eco-Tourism and Water for Life. All of the activities, workshops and seminars cost money. In a developing country like Indonesia with high levels of poverty, it would only be children and young teens from higher income families who could afford to participate. Even school groups would have to come from elite private or academic selective schools. For example, the listed cost of a Sahabat Alam national park excursion per pupil in 2013 was Rp. 250,000.00 - about US\$23. Given that the average household income per annum in Indonesia is estimated at only around 12 million rupiah - about US\$1,195 (Samboh, 2012), such excursions would be beyond the financial reach of all but the children of higher income earners. Moreover, reading the Sahabat Alam website would depend on access to the internet and English language competence. These are both middle class capacities of children and young teens in Indonesia. It is notable that participation in the listed activities requires permission and payment from parents even though it is aimed at a youth demographic. It seems the Sahabat 
Alam website sets out to attract youth who will then put pressure on their parents to purchase for them the environmental learning activities on offer.

One section of the Sahabat Alam website describes a project that supplies free sustainable power to villages through installation of a waterwheel device that uses waterfall energy. The given formula is: Power $=$ Head $x$ Flow x Gravity,

The potential electricity we will supply is based on surveys and research on the location combined with our school knowledge of Science, Electricity, Mathematics and Physics. This knowledge will definitely help us in providing a new source of energy that is environment-friendly without damaging mother nature (in English).

Readers are thus invited to assist in this "green" science project helps the poor. The use of the third person plural - we, our - encodes the idea that both Sahabat Alam organisers and potential project participants are all well-educated children together. With their shared knowlede of science and technology they can provide sustainable power and thereby function as friends for the poor village children - who are not like them. They will "help them fulfil their dreams". With electric light the poor children will be able to study at night, and so can better themselves. Green science and philanthropy form an attractive learning package in this project brief. Notably, the cost of participation is quite high given that it involves chaperoned travel and accommodation.

The Sahabat Alam website carries little on environmental destruction and degradation, climate change or lack of regulation. Rather, the emphasis is on the beauties of nature, environmental conservation and habitat improvement, encoding the romantic gaze of Indonesian conservationism. This is the focus of the rather limited environmental conscientization attempted by Sahabat Alam. Difficult issues are sidelined. Both the imagery on the website and the voice of the accompanying text is upbeat and inviting; promising fun, with simple messages and heroic stories that convey optimism. As we shall see, the second ENGO - Tanam Untuk Kehidupan or TUK - also faces the challenge of avoiding pessimistic environmental discourse and promising fun, but does so in a different way, by emphasising creativity.

\subsection{TUK - Tanam Untuk Kehidupan}

While Sahabat Alam claims to be a nation-wide organisation that speaks to children and young teens, Tanam Untuk Kehidupan - literally Planting for Life - works in a local community. The symbolism of Tanam untuk Kehidupan dedicates a project of environmental conscientization to be nurtured (grown) through collective artistry and activism. TUK afficionados are linked by mutual arts practice and local fund-raising endeavours. TUK was formed in 2005 when an artist and his Australian partner returned to the Javanese city of Salatiga. An activist arts collective grew up around them. TUK is now a non-profit organisation (lembaga) linked to a large network of art and environmental communities and organizations, local and international. TUK originally campaigned to protect water sources in Salatiga neighbourhoods where ancient springs were facing depletion and contamination. They began by holding a water festival (Festival Mata Air) in July 2006 over three days of art, music and education. It was co-sponsored by Indonesian cigarette company Djarum and local government. TUK today continues to build environmental awareness and action through creative practice, festivals and art events. The workshops and annual festivals are advertised by local radio, posters and flyers, so knowledge about them does not depend on young people's internet access and grasp of English.

Like Sahabat Alam, most of the official website is in English. However, there is an alternative blogsite, much less sophisticated, in Indonesian and a Facebook page in Indonesian. On the home page of the official TUK website the following statements appear:

TUK's Vision: To help protect a sustainable environment for future generations.

TUK's Mission: To plant sustainable environmental awareness and education in the community through art and cultural practice.

Further upbeat explanation is offered:

TUK (Planting for Life) believes that to plant an environmental ideology is as important as planting trees itself. We use art and creative practice as a medium to provide basic information and knowledge about our local and global environment and what we can all do to make changes on a daily basis. Our campaign aims to make people start THINKING! This is where the process of change begins.

\subsubsection{Environmental Conscientization}

This is a statement about experiential pedagogy towards environmental conscientization. It implies the ideal of 'agent of change' and directly refers to both "ideology" and "our campaign", implying grassroots political 
activism. Once again there is plenty of learning by doing on offer. According to press coverage - in Indonesian (Vistika, 2013), TUK has three divisions. First, the Community Services Division engages social activities such as planting trees and local capacity-building. Second, the Campaign and Publication Division organises the annual arts and culture festival. Third, the Division of Merchandising organises the making of recycled products. Plastic waste and paper is recycled by volunteers into bags, wallets, key chains, jewellery, and magnets. Shoes and slippers ae made from water hyacinth harvested sustainably from a local swamp. Products are sold under the brand name Green, Creative, Smart. In other words TUK offers informal education for young people to be community workers, event organisers or craft workers, as well as facilitating their creative expression, all relevant to environmental sustainability. However, unlike Sahabat Alam, membership and participation are not limited by economic status. Readers are assured that if interested in joining, "you just have to be aware of and concerned about the environment" (Vistika, 2013). There are no fees as such.

TUK members commit to regularly attend meetings once every two weeks. However, "if you really want to be a member of the community but cannot follow the meeting schedule you can register as a volunteer", according to Eric, current chair of TUK (Vistika, 2013). From the photos and online reports, it seems that numerous young volunteers do register, especially to assist with the annual festival. So although the local community of Salatiga is the intended target of awareness-raising, the TUK collective includes young Indonesians from further afield who care about the environment and express themselves in the arts. It is notable that there are more young men than women apparently involved in TUK, whereas Sahabat Alam would seem to have far more young women involved. A subtly gendered pedagogic discourse can be observed in each.

In terms of who young people might identify with, TUK website photos in 2013 depicted young men playing music, creating artworks and having meetings. While smiling children and young women did feature in shots from the festivals, they do not seem to be much involved in the organisation itself. Many of the young men with their scruffy clothes, tattoos and long hair seem to be both indie artists/musicians and environmental activists. Their dominance on the TUK website, on the TUK blogsite and on the TUK Facebook page appears to confirm the claim of "macho environmentalism that appeared in the 1990s in Central Java and elsewhere in Indonesia" (Crosby, 2013, p. 68). Young male environmental activists with creative talents are specific agents of change who might well imagine the space of Indonesian environmentalism in terms of political reform. This would in turn shape and configure the environmental conscientization they experience through learning as creative doing. In that sense, TUK is engaging an informal pedagogy on two or more levels. First, the TUK members and volunteers learn by collectively organising and making art and music with environmental themes. Second, the wider public of Salatiga learns about local sustainablity through enjoyable participation in children's activities, mural painting, exhibitions, forums, reforestation, Clean Up events and environmental film screenings as well as the annual festival. Third, artists and green activists in the region can gather where the action is. For example, Kafé Olé in Salatiga regularly offers live music and art shows. It is an informal meeting place for TUK members and others who might want to get involved. The café is publicised on the TUK Facebook page (Indonesian language).

Finally, international artists and activists come in for residencies at TUK to learn about environmentalism in Indonesia. For example, the 2012 TUK program theme was "CATCH WATER - PLANT TREES". Apart from the annual arts festival, there were workshops, international artist residencies, tree-planting and a recycled trash craft program. TUK has attracted some significant international sponsorship. It seems clear that the TUK collective encourages a kind of local tribalism among creative conservationists from an older demographic of young people - the majority male and artistic, who are not constrained from participation by household income. They learn by doing as a collaborative endeavour.

\section{Discussion of Findings}

The simple and straightforward message of environmentalism could be stated as: "The natural world is being destroyed and it is a moral imperative to preserve and reconstitute as much of it as possible as soon as possible" (Lakoff, 2010, p. 80). Yet as Gidddens (2011, p. 1) points out, environmentalism is not just about "nightmares" and "catastrophes", but "dreams". Both Sahabat Alam and Tanam Untuk Kehidupan avoid the catastrophic and sideline the factual in favour of dreams as a pedagogic medium. Optimistic visions of saving the environment are offered to young Indonesians within a broadly reformist political frame. Yet the two organisations provide discourses of enjoyable praxis that configure quite differently the pedagogic space of experiential learning for children and young people. Table 1 formally compares the two groups. 
Table 1. Comparing key features

\begin{tabular}{|c|c|c|}
\hline Features & Sahabat Alam & Tanam Untuk Kehidupan \\
\hline Based in & $\begin{array}{l}\text { Jakarta, the national capital and the most } \\
\text { climate-change sensitive mega-city in Southeast } \\
\text { Asia (Savage, 2012, p. 230). }\end{array}$ & $\begin{array}{l}\text { Salatiga, a small city in a mountainous } \\
\text { region of Central Java. }\end{array}$ \\
\hline Governance structure & Top down hierarchy. & Collective with rotated chair. \\
\hline Leadership & $\begin{array}{l}\text { Sole young female founder and director, leads } \\
\text { directly, high profile. }\end{array}$ & $\begin{array}{l}\text { Married international couple as founders, } \\
\text { leadership now rotates. }\end{array}$ \\
\hline Members & Young people, both sexes & $\begin{array}{l}\text { Young creative artists, musicians, activists, } \\
\text { majority male }\end{array}$ \\
\hline $\begin{array}{l}\text { Pedagogic mode of } \\
\text { engagement }\end{array}$ & $\begin{array}{l}\text { Experiential learning through structured activities, } \\
\text { exposure to national parks }\end{array}$ & $\begin{array}{c}\text { Experiential learning informed by a creative } \\
\text { DIY ethos, intensive learning in the local } \\
\text { community }\end{array}$ \\
\hline Educational target & Indonesian children, young teens, both sexes & $\begin{array}{l}\text { Local community members and regional } \\
\text { citizens, all ages, both sexes }\end{array}$ \\
\hline Cost of involvement & Relatively high & None \\
\hline Focus on nature & $\begin{array}{c}\text { Trees, species protection, coastal regeneration, } \\
\text { national parks }\end{array}$ & Trees, water, human-nature relationship \\
\hline $\begin{array}{l}\text { Visual imagery on } \\
\text { website }\end{array}$ & $\begin{array}{l}\text { Simple, child-like, cartoon genre, bright colours, } \\
\text { stylised plants, animals }\end{array}$ & $\begin{array}{l}\text { Expressionist art, sculpture, earthy colours, } \\
\text { natural materials, political symbols, } \\
\text { caricature and satire }\end{array}$ \\
\hline Photo gallery & $\begin{array}{l}\text { Young female leader with: groups of school } \\
\text { children, international dignitaries; engaged in } \\
\text { conservation activities, expeditions to national } \\
\text { parks }\end{array}$ & $\begin{array}{l}\text { Young male groups (musical, artistic, } \\
\text { activist), community participation, art } \\
\text { works, musical performances, water sources }\end{array}$ \\
\hline Language & Same website offers English and Indonesian & $\begin{array}{l}\text { Different websites for Indonesian and } \\
\text { English }\end{array}$ \\
\hline Litter removal actions & Collect and dispose & Collect and re-use \\
\hline International links & $\begin{array}{l}\text { Awards, competitions, conferences, regional } \\
\text { business and industry sponsorship }\end{array}$ & $\begin{array}{l}\text { Aid donors, artistic and philanthropic } \\
\text { organisations }\end{array}$ \\
\hline $\begin{array}{l}\text { Number of Facebook } \\
\text { members in December } \\
2013\end{array}$ & 214 & 913 \\
\hline YouTube postings & Yes & Yes \\
\hline $\begin{array}{l}\text { Regular television } \\
\text { presence }\end{array}$ & Yes & No \\
\hline
\end{tabular}

Based on the table above, we can see many points of dissimilarity between the two organisations in constituting the discursive space of non-formal pedagogy. On its website, Sahabat Alam uses top-down, vertical discourses to mobilize young Indonesians as consumers of ideas who learn about conservation of the natural world through structured activities and thus become environmental ambassadors for the future. Fun and socialising are emphasised. The strongly positive and cheerful tone of the website suggests that the organisation is aware young people may be turned off by environmental messages that make them feel worried and guilty. Conversely, while there are plenty of ideas to be consumed on the TUK website, environmental discourses are channelled laterally; mobilizing young artists and activists to create art, craft and events that will educate the local community and visitors to festivals and residencies. Fun and socialising are emphasised here also, especially at festivals. The strong emphasis on creativity, self-expression and enjoyment on the two TUK websites and the TUK Facebook page similarly indicate awareness that young people may avoid environmental learning events that make them feel concerned yet powerless.

Sahabat Alam and TUK also differ in what they teach about the stewardship of nature. In the discourse of Sahabat Alam, the natural world is "out there", beyond the cities and the everyday experience of people's lives. It is to be learned about through structured activities, then assisted for preservation. In contrast, the discourse of TUK advances the idea that the natural world is right here and now in the local community and its constituencies. So environmental learning does not take place in structured activities and programs, but in local artistic creation and subsequent appreciative engagement. The natural world and conservation concerns are mediated through 
creative representation so that ordinary local people will take up responsibility for preserving their immediate environment.

A further point of difference is the celebrity factor. The cult of celebrity is big business in Indonesia (Coutas, 2006). It can be argued that celebrities are the new "charismatic megafauna" of the environmental movement (Boyokoff, Goodman, \& Littler, 2010, p. 1). The authority of the celebrity creates the permissible, the normal and the desirable in environmentalist discourse. Celebrities are thus an important 'branding tool' for environmental causes because of the increasing sophistication of branding and social marketing elsewhere in the social fabric (Boyokoff, Goodman, \& Littler, 2010, p. 6). In pedagogic terms, the celebrity environmentalist functions as a kind of teacher. Adeline identifiably occupies this position in Sahabat Alam. Conversely, there is no single celebrity leader as teacher in TUK. Rather the artists and activists learn from each other and the community learns from them. This explains why children and young teens who are still at school might be drawn to Sahabat Alam. The overall pedagogic discourse resembles the teacher-driven transactions of learning with which they are familiar in the classroom. TUK on the other hand constitutes a lateral and collaborative pedagogic discourse of environmental learning that matches grassroots artistic praxis. Maffesoli (1996, pp. 1-2) identifies this social movement praxis as a space where transformative potential, "is characterised by puissancethe 'energy and vital force of the people' rather than pouvoir - top-down institutionalised power". A very different constitution of learning prevails in the two organisations. They differ significantly in terms of pedagogic style.

First, the educative orientation of Sahabat Alam is small to big in that a limited number of members travel out to facilitate the experiential learning of children and young teens across the nation (in theory), while TUK proffers a big to small orientation - national and international visitors are brought into the local community for experiential learning. Second, while Sahabat Alam offers a more or less traditional transactional model of learning, shaped by the commodifying influence of financial cost, TUK offers a free, carnivalesque learning experience. For Bakhtin (1941, p. 199), carnival is "the feast of time, the feast of becoming, change and renewal". It is associated with the sense of collectivity among those who gather in "the town square", since all are considered equal during carnival. Free contact takes place among people who are usually divided by "caste, property, profession, and age" (Bakhtin, 1941, p. 10). Carnival constitutes a challenge to the dominant order, enabling access to "the below, the underworld, and the march of the uncrowned gods" (Hall, 1997, p. 291). Visual imagery of large grotesque figures and confronting installations attest to the carnival nature of the annual TUK water festival. Third, by further comparison, the activities offered by Sahabat Alam promise a clean, smooth and predictable learning experience, while TUK activities provide messy and unpredictable experiences of a creative and therefore more risky nature. Finally, the nature of the implicit subject produced by the pedagogic style of the two ENGOs demonstrates a contrast. The drive of Sahabat Alam is to give experiential knowledge to produce young people who will help preserve the natural environment and represent it as ambassadors. The drive of TUK is to encourage people to live in harmony with nature at close quarters. Here humans are linked to their environment through deep knowledge gained through the carnivalesque celebration of the natural world and creative interrogation of the human-nature relationship.

\section{Conclusion}

Conscientization - in Freire's terms - is an active process that comes from intensive learning as doing. In the contemporary socio-cultural context of Indonesia, the two ENGOs examined here offer contrasting pathways to transform young people into stimulating agents of change. Yet non-formal environmental learning cannot afford to be dull, so both ENGOs visually emphasise young people having fun together on their websites and Facebook pages. They also offer different discursive resources.

Sahabat Alam invites the participation of children and young teens who constitute themselves as rather conservative learners about the natural world. It carries on the historical tradition of student nature lover clubs. TUK however, invites the participation of young people, young men in particular, who want to take a challenging, radical approach to raising environmental awareness through creativity, art and celebration. TUK is therefore a more active politically reformist organisation. As for pedagogic discourse, the local tribalism of TUK provides collective learning about the environment by doing creative things together and inspiring others to re-imagine their relationship with nature. Sahabat Alam on the other hand, offers a model of non-formal learning that is much more like school, with emphasis on the leader/teacher and a standardised set of activities to bring about specific learning outcomes. These two discourses of pedagogy are even further distanced from each in the matter of financial costs. Sahabat Alam charges relatively high fees for learning activities, while TUK is free. So TUK potentially reaches a much broader demographic of young people, including those from poor families, yet is constrained by local boundaries. 
In summary, comparison of these two youth-oriented ENGOs allows us to see not only how they differ pedagogically, but differ in the kind of human-nature relationship each hopes to produce in the coming generation of Indonesians. The environmentalists of the future will make active decisions about conservation and sustainability behaviour. In the implied discourse of Sahabat Alam they will save the natural environment of the nation through conservation efforts and the application of science and technology. In the implied discourse of TUK they will live closely with the local natural environment and express this relationship creatively. The first seems highly anthropocentric and the latter less so. Yet beyond their differences, at a deeper level both the lateral carnivalesque pedagogy of TUK and the top-down transactional pedagogy of Sahabat Alam favour the romantic gaze of environmentalism, foregrounding heroic dreams and fun rather than facts and looming catastrophic scenarios. The implication for the Indonesian environmental movement is that informal environmental education at the micro level matters as much as international agreements at the macro level. Informal environmental education sensitises ordinary young people to key environmental problems and provides opportunities for pro-active engagement that points the way to transformative ethical action in the future.

\section{Acknowledgments}

This research was carried out with the support of the Australian Research Council. Grant Number: ARCDP DP130100051.

\section{References}

Anderson, B. (1991). Imagined communities: Reflections on the origin and spread of nationalism. London \& New York: Verso.

Babbie, E. R. (2010). The practice of social research (12th ed.). Wadsworth: Cengage Learning.

Bakhtin, M. (1941). Rabelais and his world. Bloomington: Indiana University Press.

Bohensky, E. L., Smajgl, A., \& Brewer, T. (2012). Patterns in household-level engagement with climate change in Indonesia. Nature Climate Change, 3, 348-351. http://dx.doi.org/10.1038/NCLIMATE1762

Boyokoff, M., Goodman, M., \& Littler, J. (2010). "Charismatic megafauna": The growing power of celebrities and pop culture in climate change campaigns. Paper \# 28, Environment, Politics and Development Working Paper Series. London: Department of Geography, King's College, 1-12. http://dx.doi.org/10.1177/107 5547008329201

BPS. (2012). Statistik Indonesia 2012. Jakarta: Badan Pusat Statistik (Online). Retrieved June 9, 2013, from http://www.bps.go.id

Carlson, K., Curran, L., Ratnasari, D., Pittman, A., Soares-Filhof, B., Asner, G., \& Rodrigues, H. (2012). Committed carbon emissions, deforestation, and community land conversion from oil palm plantation expansion in West Kalimantan, Indonesia. PNAS - Proceedings of the National Academy of Sciences, 109(19), 7559-7564. http://dx.doi.org/10.1073/pnas.1200452109

Cochrane, J. (2006). Indonesian national parks: Understanding leisure users. Annals of Tourism Research, 33(4), 979-997. http://dx.doi.org/10.1016/j.annals.2006.03.018

Coutas, P. (2006). Fame, fortune, fantasi: Indonesian Idol and the new celebrity. Asian Journal of Communication, 16(4), 371-392. http://dx.doi.org/10.1080/ 01292980601012410

Crosby, A. (2013). Remixing environmentalism in Blora, Central Java 2005-10. International Journal of Cultural Studies, 16(3), 257-269. http://dx.doi.org/10.1177/1367877912474535

Escobar, A. (1999). After nature: Steps to an anti-essentialist political ecology. Current Anthropology, 40(1), 1-30. http://dx.doi.org/10.1086/515799

di Gregorio, M. (2012). Networking in environmental movement organisation coalitions: interest, values or discourse? Environmental Politics, 21(1), 1-25. http://dx.doi.org/10.1080/09644016.2011.643366

Dimitriadis, G. (2009). Performing identity, performing culture: Hip hop as text, pedagogy and lived practice (Revised ed.). New York: Peter Lang.

Douglass, M., Le, T.Q., Lowry, C. K., Nguyen, H. T., Pham, A. N., \& Thai, N. D. (2008). The liveability of mega-urban regions in Southeast Asia - Bangkok, Ho Chi Minh City, Jakarta and Manila compared. In G. W. Jones, \& M. Douglass (Eds.), Mega urban regions in Pacific Asia (pp. 45-56). Singapore: NUS Press.

Fadaee, S. (2011). Environmental movements in Iran: application of the new social movement theory in the non-European context. Social Change, 41(1), 79-96. http://dx.doi.org/10.1177/004908571104100104 
Freire, P. (1997). Pedagogy of the oppressed. New York: Continuum

Galang, A. P. (2010). Environmental education for sustainability in higher education institutions in the Philippines. International Journal of Sustainability in Higher Education, 11(2), 173-183. http://dx.doi.org/10.1108/14676370210434741

Gee, J. P. (2014). An introduction to discourse analysis: Theory and method (4th ed.). New York: Routledge.

Giddens, A. (2011). The politics of climate change (2nd ed.). London: Polity Press.

Hadiwinata, B. (2003). The politics of NGOs in Indonesia: developing democracy and managing a movement. London: Routledge Curzon.

Hall, S. (1997). Representations. London: Sage.

Ifham, A., \& Helmi, A. (2002). Hubungan kecerdasan emosi dengan kewirausahaan pada mahasiswa. Jurnal psikologi. Yogyakarta: Universitas Gadjah Mada. Retrieved January 18, 2014, from http://www.avin.staff. ugm.ac.id/data/jurnal/kecerdasanemosi_avin.pdf

Inthorn, S., \& Reder, M. (2011). Discourses of environmental citizenship: How television teaches us to be green. International Journal of Media and Cultural Politics, 7(1), 37-54. http://dx.doi.org/10.1386/mcp.7.1.37_1

Kementeriaan Lingkungan Hidup. (2004). Kebijakan pendidikan lingkungan hidup. Jakarta: Republik Indonesia Press. Retrieved April 3, 2013, from http://www.blhmuaraenim.com/wp-content/uploads/2012/11/02Sambutan.pdf

Kusmawan, U. (2007). An analysis of student environmental attitudes and their impact on promoting sustainable environmental citizenship: a multi-site study in Indonesian secondary schools ( $\mathrm{PhD}$ thesis). University of Newcastle, Australia.

Kollmuss, A., \& Agyeman, J. (2002). Mind the gap: why do people act environmentally and what are the barriers to pro-environmental behavior? Environmental Education Research, 8(3), 239-260. http://dx.doi.org/10. $1080 / 13504620220145401$

Lakoff, G. (2010). Why it matters how we frame the environment. Environmental Communication: A Journal of Nature and Culture, 4(1), 70-81. http://dx.doi.org/10.1080/17524030903529749

Macnaghten, P., \& Urry, J. (1998). Contested natures. London: Sage.

Maffesoli, M. (1996). The time of the tribes. London: Sage.

Measey, M. (2010). Indonesia: a vulnerable country in the face of climate change. Global Majority E-Journal, 1(1), 31-45. Retrieved April 4, 2013, from https://www.american.edu/cas/economics/ejournal/upload/ Global_Majority_e_Journal_1-1_Measey.pdf

Nomura, K. (2009). A perspective on education for sustainable development: historical development of environmental education in Indonesia. International Journal of Educational Development, 29, 621-627. http://dx.doi.org/10.1016/j.ijedudev.2008.12.002

Parker, L. (2011). Teaching environmental citizenship in Indonesia. Paper presented at Indonesia Council Open Conference, University of Western Australia, Perth 26-28, September 2011.

Parker, L., \& Nilan, P. (2013). Adolescents in contemporary Indonesia. London \& New York: Routledge.

Parus. (2005). Department of National Education: partnership for environmental education in primary and secondary education. In K. Nomura, \& L. Hendarti (Eds.), Environmental education and NGOs in Indonesia (pp. 65-76). Jakarta: Yayasan Obor Indonesia.

Riemer, M., Lynes, J., \& Hickman, G. (2014). A model for developing and assessing youth-based environmental engagement programmes. Environmental Education Research, 20(4), 552-574. http://dx.doi.org/10.1080/ 13504622.2013 .812721

Samartan, N. (2009). Strategi pengembangan media: Antara bisnis dan ideologi. Jurnal Ekonomi Bisnis, 3(14), 190-199. Retrieved April 4, 2013, from http://ejournal.gunadarma.ac.id/index.php/ekbis/article/view/366

Savage, V. R. (2012). Climate change and Southeast Asian urbanization: mitigation and adaptation considerations. In Y. K. Sheng, \& M. Thuzar (Eds.), Urbanization in Southeast Asia: Issues and impacts (pp. 229-261). Singapore: Institute of Southeast Asian Studies. http://dx.doi.org/10.1080/00074918.2014.896312

Setiawan, M., Stoetter, J., Sartohadi, \& Christanto, N. (2009). The integrated soil erosion risk management model of Central Java, Indonesia. Geophysical Research Abstracts, 11, 6802. Retrieved December 31, 2012, 
from http://adsabs.harvard.edu/abs/2009EGUGA..11.6802S

Stalley, P., \& Yang, D. (2006). An emerging environmental movement in China? The China Quarterly. http://dx.doi.org/10.1017/S030574100600018X

Sudamardi, S., Suzuki, S., Kawada, T., Netti, H., Soemantri, S., \& Tugaswati, A.T. (2001). A survey of perception, knowledge, awareness and attitude in regard to environmental problems in a sample of two different social groups in Jakarta, Indonesia. Environment, Development and Sustainability, 3(2), 169-183. http://dx.doi.org/10.1023/A:1011633729185

Tsao, T. (2013). Environmentalism and civilisational development in the colonial British histories of the Indian archipelago (1783-1820). Journal of the History of Ideas, 74(3), 449-471. http://dx.doi.org/10.1353/jhi.2013. 0027

Vistika, F. B. (2013). Komunitas tanam untuk kehidupan [TUK: nature through the arts]. Kontan Online 4 June 2013. Retrieved January 19, 2014, from http://lifestyle.kontan.co.id/news/tuk-alam-lestari-lewat-seni

World Bank. (2009). Indonesia rising: mainstreaming climate change for sustainability. Jakarta: World Bank. Online. Retrieved December 30, 2012, from http://go.worldbank.org/JIGX6UTVJ0

World Bank. (2010). Indonesia: climate change. Washington: World Bank. Online. Retrieved December 30, 2012, from http://go.worldbank.org/HQQFW5MV70

World Bank. (2011). World Bank and environment in Indonesia. Online. Retrieved December 30, 2012, from http://go.worldbank.org/QQE3DLKB20

World Bank. (2013). Indonesia overview. Retrieved August 26, 2013, from http://www.worldbank.org/en/ country/indonesia/overview

Wray-Lake, L., Flanagan, C., \& Osgood, W. (2010). Examining trends in adolescent environmental attitudes, beliefs and behaviors across three decades. Environmental Behavior, 42(1), 61-85. http://dx.doi.org/10.1177/0013916509335163

Xie, L. (2010). China's environmental activism in the age of globalization. Asian Politics \& Policy, 3(2), 207-224. http://dx.doi.org/10.1111/j.1943-0787.2011.01256.x

\section{Note}

Note 1. In Indonesia tobacco companies are major sponsors of sport and and the arts. In many other countries this is not permitted. There is admittedly some irony in a cigarette company sponsoring a festival to raise environmental awareness.

\section{Copyright}

Copyright for this article is retained by the author(s), with first publication rights granted to the journal.

This is an open-access article distributed under the terms and conditions of the Creative Commons Attribution license (http://creativecommons.org/licenses/by/3.0/). 